\title{
Financing and Success/Performance of Small Businesses in Serbia
}

\author{
DOI:10.7595/management.fon.2020.0022
}

\begin{abstract}
:
Financing represents a general problem for small enterprises with numerous constraints. Defining the problem of research will eliminate the answer to the following research question: Does the financing of small enterprises, based on the volume and structure, determine business performance, i.e., success? As well as the overall problem orientation of this research, motivation is related to the analysis of business performance, i.e., success of small enterprises in relation to the nature of financing small businesses. It has to be defined 'The idea is to identify and define the role of financing as a factor of competitiveness and performance in small business operations, as the general objective of the paper. Lack of financial resources is one of the most common causes of failure of small enterprises. The main hypothesis is: There is a significant correlation between the volume and structure of sources of financing and the performance of small enterprises. Data: Secondary data from the reference databases (Serbian Business Registers Agency) for 2018, which include 150 cases, serve as the relevant basis for the realization of the research within the adequately set area of the research. Tools will be used to study the relationship, i.e., connectivity of selected research variables based on regression analysis in the frame of parametric quantitative procedures. Business performance variables, measured by indicators of profit and revenue growth, with variables of volume and structure of financing as is equity and \% of equity as a structure; measures like time in business, total revenue, total number of employees, represent the size and age of business. Findings point to the conclusion that the volume of financing as well as the participation of own capital contribute to the business performance of small enterprises, which is measured by the most relevant variables in terms of profit and total revenue. Contribution: Based on the facts presented, we can say that all research assumptions have been confirmed, and the presented research results are significant and representative for future managerial practice of small businesses. The key contribution of this research is identification of an optimal financing structure for business performance of small enterprises.
\end{abstract}

Keywords: small businesses, financing, capital structure, success, performance

JEL Classification: M13, L25, G32

\section{Introduction}

It is not hard to notice within the selected field of research and relevant scientific literature that small enterprises have a great importance and role in the economic and overall social development of a country. Due to the importance of small enterprises and their specificity in contrast to medium and large enterprises, the selected field of research is small enterprises operating in Serbia. The sub-segment of micro enterprises is excluded from the scope of research. In order to determine the stated field of research precisely, it is necessary to point out the characteristics of small enterprises from a quantitative and qualitative aspect owner/entrepreneur/manager. In addition to non-existent or inadequate management practices, some of the crucial problems encountered by small businesses, are limited resources and financial instability (Scarborough, 2012). Therefore, it is necessary to point out first of all the potential sources of financing of a company, but also the availability and importance of certain sources of financing for small enterprises. Some 
characteristics of small enterprises largely determine their financing structure as well as the capital structure, understood as a long-term aspect of the financial structure of the company, which significantly differentiates them from the financing structure and capital structure of large enterprises.

It is also very important to note the necessity of precise attitudes and a full understanding of the meaning of certain categories in order to make the results of this research clear and unambiguous and fully usable. The need to separate success and performance as well as their definition arises for the reason that these categories represent key variables in the research. The notion of the performance of small businesses, that is, the owner/ entrepreneur/manager's success, we could say, is a subjective category as a measure in achieving a set of the company goals that can be unambiguous and reflect individual motives. Due to all its specificity in terms of, above all, business capacity, the competitiveness of small enterprises is a very sensitive segment. Also, an important factor of competitiveness is financing of small enterprises observed from the aspect of the structure of sources, and therefore the availability of financial resources. A highly significant outcome in this area is that numerous employees who are, in fact, members of the entrepreneur's family, as well as the consequent insufficiently defined hierarchy, may jeopardize a company's performance in terms of annual sales of goods and services and annual profits. A very important result in this area is that a large number of family member employees, and unclear hierarchy among them, can endanger a company's success in terms of annual income and annual turnover (Mihic et al., 2015). A result like this represents a sufficient reason for defining the research area precisely.

The financial market in Serbia shows a low level of activity, what can be concluded based on the Global Competitiveness Report for 2017, where access to finance is cited as one of the most problematic factors for doing business. The specific features of small businesses that determine the limitation of some sources of finance have the effect of making the issue of financing small businesses one of the key issues, given that access to finance is one of the key factors of competitiveness of small enterprises. This taken into consideration, the situation should be viewed in two ways. First of all, to what extent do small enterprises fulfil the necessary conditions in terms of adequate users of certain sources of financing in the form of creditworthiness and, second, availability of financial resources on the market. In this way, we will attempt to explain how the limited access of small enterprises to different sources of financing reflects on their success/performance by analysing the existing financing structures of these enterprises. Accordingly, the central research question is: Does the financing of small enterprises, based on the volume and structure, determine business performance, i.e., success? In this respect, the clarification and understanding of the concept of small business success is very important, and a distinction will be made between the terms success and performance, which are often highly interconnected, and are even considered to be synonyms.

\section{An Overview of Prevailing Views in the Field of Research - from Entrepreneurial Ventures to Small Enterprises}

Stokes and Wilson (2010) made a distinction between entrepreneurs and small enterprises, stating that the entrepreneur is an individual or a group of individuals acting as the main actors in the process of implementing an entrepreneurial idea, while a small enterprise is a certain organizational and legal form that is the result of an entrepreneurial process, as a next phase in the maturity of a business venture. The authors also distinguish the quantitative and the qualitative definitions of small businesses. The quantitative definition is based on the number of employees, the amount of revenue and total assets, which, as criteria for defining, vary from country to country. According to the Law on Accounting and Auditing of the Republic of Serbia ("Official Gazette of the Republic of Serbia", No. 62/2013 and 30/2018), the boundary values of these indicators are clearly defined, of which enterprises should meet the reference value in at least two of the above criteria in order to be classified into one of the categories of a vertical economic structure. When it comes to the qualitative aspect of small businesses, Stokes and Wilson (2010) point out that this aspect is based on three distinctive features of small businesses:

1) A small enterprise is usually managed by one owner;

2) A small enterprise has a relatively small share in the market;

3) It is independent in decision making process because the owner does not depend on other companies or shareholders.

Burns and Dewhurst (1996) reported that small enterprises tend to be managed in a personalized way. This can be interpreted through the fact that the owner has an active participating role in all facets of the management process and every higher-level decision-making event. Similarly, Hill (2001) points out that one of the basic specifics of small businesses is a high involvement of the entrepreneur. The owner-manager seems to be part of every business action. According to Cuervo, Ribeiro and Roig (2007), the owner of a 
small company is an individual who sets up and runs a company to achieve the foremost goal of pursuing personal ambitions. The predominant business activities need to be the principal income source, thus absorbing most of the entrepreneur's time, as well as employing the company's resources. The company owners consider the business to be an integral part of their personality, interwoven with the family's requirements and aspirations. What separates a small enterprise from an entrepreneurial venture is the existence of a strategic, long-term orientation or the existence of aspirations for sustainability (Wickham, 2004). Essentially strategic orientation implies the existence of a long-term commitment of small businesses to accomplish business activities that are defined in strategic goals and defined by the mission and the vision of a business (Lekovic \& Maric, 2015).

Jennings \& Beaver (1997) note that, regardless of the need for generic skills and abilities, the process of running small companies is different from routine and cannot be viewed by the same yardstick as professional management in larger enterprises reduced to a smaller scale in practice. The diversity of roles required of the owner-manager as the primary stakeholder frequently results in disharmony and antagonism, raising the possibility of improper decision-making, or even incongruous actions. Therefore, these authors are of the opinion that the main cause of poor performance of small businesses is almost invariably a lack of management attention to strategic issues. The existence of a managerial orientation clearly separates a small enterprise from an entrepreneurial venture, but also an initial management practice qualitatively segregates small businesses from the medium-sized to a significant extent, as the next stage in development, where management is present at a higher, professional level. Strategic management is vital for long-term competitiveness of small and medium-sized enterprises, and even more important in coping with crises. Companies that pursue strategic management are capable of looking ahead into the time to come, so that their leaders have the opportunity and possibility to identify future problems beforehand, so that they can get ready for them far better. A successful manager of small and medium-sized enterprises must have a vision of the future development of their enterprise (Vrchota \& Rehor, 2017).

\subsection{Financing as a Determinant of Success / Performance of Small Enterprises}

To make a decision on financing, it is necessary to take into account the characteristics of the enterprises (size, industry, growth opportunities, the structure of assets, etc.) and choose the structure of debt and equity, which defines the financing structure of the company. The defined rules of financing represent the norms and standards that must be observed for the company to have a steady, liquid and profitable business, based on the relationship between fixed and current assets in the active capital and its own (longterm) and borrowed (long-term and short-term) assets, which represents the structure of the sources of financing (Vuckovic et al., 2017).

The long-term aspect of the financial structure of the company, understood as the ratio of own and borrowed sources of funds, is known as the capital structure of the company (Ivanis, 2012). Thanh and Huong (2017) noted that the capital structure studies explore the influence of company-specific and state-specific factors on financing models of companies in particular areas. Some company-specific factors that are mainly considered are profitability, opportunity for growth, tangibility, corporate tax shield, non-debt tax shield, size of company, uniqueness of industry and some macroeconomic factors such as rate of inflation and condition of capital market. However, it is unrealistic to expect that the growth and development of the company, as one of the crucial goals of the company, can be financed exclusively from its own and from those informal external sources, primarily because of their limitations. In order to increase profitability, it is essential for managers to concentrate their attention and efforts on amounts due from customers and stockpile control, which can be managed and tackled with stricter credit practices or lean manufacturing tools (Hogerle et al., 2020).

Cressy and Olofsson (1997) state that smaller businesses are more prone to financial risk, hence, as a consequence, they are exposed to more strains searching for external financing sources. According to Jakovcevic et al. (2012), one of the biggest problems faced by small enterprises is the provision of financial resources, and they emphasize that financial institutions are hesitant when it comes to granting loans to small companies due to uncertainty of their business.

Berger and Udell (1995) argue that minor and more recently set up companies are more probable to be exposed to higher cost of borrowing, i.e., interest rate, and obliged to provide a collateral. Walker (1998) notes that many of the traditional sources of financing are not available to small businesses, and since small businesses have less affordable long-term sources or capital in traditional financial markets, they must rely on trade credits and bank loans. Consistently with earlier published sources, our research establishes that the capital structure of small companies is based on short-term loans or, more particularly, on trade credit. 
Furthermore, inadequate availability of external financing sources is an obstacle to small and medium-sized companies when attempting to expand their business operations, because of insufficient communication between financial intermediaries and small and medium-sized companies (D'Amato, 2019; Motta, 2020). A large amount of the capital of small enterprises comes from the own funds of entrepreneurs and informal investors that are made up of family members or acquaintances of entrepreneurs. Also, the author states that retained earnings represent a critical source of capital for small businesses. The capital structure of small enterprises significantly differs from the capital structure of large enterprises. Difficult access to financing is a much larger constraint for small enterprises than for large ones because of the dependence of small enterprises on external sources of financing and absence of management practices (Brinckmann, Grichnik \& Kapsa, 2010). Also, certain characteristics of small enterprises determine their capital structure significantly, as shown by different research. Mateev et al. (2013) maintain that the size of a company is of essence in defining leverage ratios, as major companies are characterized by far higher leverage ratios than other companies. Beck et al. (2008) conclude that small companies and companies in states with inadequate institutions are less likely to reach for external financing sources, notably loans from banks. Scherr et al. (1990) and Hamilton \& Fox (1998) argue that companies of minor size are less prone to issue equity to outsiders, so as to avoid conceding control.

Klapper et al. (2002) analyzed firm financing in 15 transition countries, including Serbia (at that time the State Union of Serbia and Montenegro). The authors find that the majority of countries are characterized by a comparatively low degree of finding financing sources from outside, with Ukraine being the most resistant. Companies in 6 (Bulgaria, Bosnia and Herzegovina, Russia, Serbia and Montenegro, Slovenia and Ukraine) out of the 15 countries have a very low debt ratios compared to companies from Western Europe. Furthermore, they hardly use any long-term loans, which is a phenomenon that could point to an underdeveloped banking sector, inadequate collateral registries and underdeveloped regulations pertaining collaterals.

The financial market in transition countries is generally poorly functioning. According to the Global Competitiveness Report for 2017 (Schwab, 2017), access to financing is stated as one of the most problematic factors in doing business in Serbia. Within the eighth pillar of competitiveness, which refers to the financial market development, most of the indicators have a very poor value and rank (compared to the 137 ranked countries) and it is particularly important to highlight the following indicators:

- availability of financial services 3.6 (107);

- affordability of financial services 3.0 (116);

- financing through local equity market 2.9 (110);

- ease of access to loans 3.6 (86);

- venture capital availability $2.6(95)$;

- regulation of securities exchanges 3.6 (109).

Those indicators reflected the difficulties of access to financing for companies in Serbia, especially for small businesses given their specific features. Malhotra et al. (2007) believe that difficult access to financing is a much bigger constraint for small enterprises than for large ones. Accordingly, we can state that the aforementioned weaknesses of small enterprises, due to the lack of strategic orientation and the lack of financial resources, are the most common causes of their failure.

Generally speaking, success implies survival and continuity, while failure is directly related to business failure (Simpson et al., 2004). Bruderl et al. (1992) and Pennings et al. (1998) define success as a duration at work. Also, success can be understood as achieving one's goals (Dobbins \& Pettman, 1997). However, understanding success of the small businesses is very specific. This particularity arises from certain characteristics of small enterprises. As mentioned above, one of the basic specifics of small businesses is a high involvement of entrepreneur, and his involvement in every business action (Hill, 2001) and so the incorporation of his beliefs, preferences, experience and expertise into the company itself (McCartan-Quinn \& Carson, 2003). It is always a question of how the characteristics and attitudes of entrepreneurs have a significant impact on the success of the company, as well as on its expression. argue that every entrepreneur has their own criteria of success. However, if the entrepreneur's subjective assessment of success is used as a measure of success, a comparison of the company on this basis would be ineffective. Whose perception would be considered relevant to assessing and comparing the performance of different companies?

In the endeavour to gain understanding of some associations and connections between the value system of entrepreneurs and the priority in their decisions to act, what needs to be viewed fundamentally are the imaginable extents and constituents of what is generally considered as a value system (Lekovic \& Maric, 2016). Based on universal requirements of human existence, the Schwartz value theory defines 10 broad values (Bardi \& Schwartz, 2003). 
What we can see in the Schwartz theory is the value orientations that are organized theoretically on the grounds of complementarities, i.e., on a contradictory character or conflicting nature of motivational aims (Lekovic \& Maric, 2016). If these elements of value orientations are presented in a circular view, which is characteristic of this author, then horizontal and vertical axes can be divided into four separate parts. One axis leads from 'self-enhancement' to 'self-transcendence', while the other goes from 'openness to change' to 'conservation' values (Schwartz, 2012), which in a mutual relationship and connections can directly determine the value system of an individual.

\subsection{Measures of small enterprise performance}

In an effort to eliminate the issue of subjective assessment of the success, a distinction is made between the concepts of success and performance, which are often highly interconnected, and are often used as synonyms. It is stated that success refers to the achievement of set goals, and the concept of the success of small enterprises or owner/entrepreneur/manager is seen as a subjective, i.e., absolute category as a measure in achieving set goals that can be simple and unambiguous and can reflect individual concerns and motives (McCartan-Quinn \& Carson, 2003). According to Brush and Vanderwerf (1992), when researchers use the word "performance", it includes numerous criteria measuring alternate angles of performance. ) interprets performance as the aptitude of an entity to generate outcomes in a predetermined dimension, relative to an objective. Therefore, for performance as a multidimensional, quantitative and qualitative expression of success in comparison with other enterprises or relevant groups of enterprises, we can say that it represents an objective, i.e., relative dimension of success (McCartan-Quinn \& Carson, 2003).

The development and expansion and of a company is normally established by its volume, which can, then, be analyzed by fluctuations in turnover, total amount of the statement of financial position, or number of workforce and through market share or the market value of the firm (Murphy et al., 1996; Virtanen, 1999). What is interesting to observe is that performance and success are, in some cases, evaluated by progress (Reijonen \& Komppula, 2007). According to Hall and Fulshav (1993) the most unmistakable yardsticks of prosperity are profitability and progress. The standards of organizational performance were concentrated on indicators of productivity, these being the most objective and commonest criteria of efficiency used in studies (Jevtic, Jovanovic, \& Krivokapic, 2018). Based on the above, it is clear that accurate assessment of performance is crucial to comprehending the success and failure of new projects and small companies (Murphy et al., 1996). Concepts of performance and success are viewed from the financial and non-financial aspects. Performance measures such as quality and time are considered non-financial indicators but can be quantified. The second group of indicators such as autonomy and job satisfaction, which are also included in non-financial measures of success, cannot be simply quantified and included in accounting operations (Reijonen \& Komppula, 2007).

It is important to emphasize that success is viewed from a broader perspective, and, as stated above, it is often assessed subjectively, while the performance is usually assessed more objectively (Reijonen and Komppula, 2007). Entrepreneurs, due to the subjective approach to the category of success, may consider that they have achieved success, while the relatively observed level of success can differ significantly (Simpson et al., 2004).

Walker and Brown (2004) suggest that the criteria of both economic and non-economic character are used to evaluate the success of a company, but the latter is more significant. Personal contentment, pride in one's position in a company and a flexible lifestyle are, in most cases, appreciated more than financial gains. According to Murphy et al. (1996), the variables used to measure performance vary to a large extent. The most commonly used measures of performance are efficiency, growth and profit. According to research conducted by Perez and Canino (2009), growth, profitability and profit are used as the most common measure of the success of small businesses. Small business owners often see the motive for starting a business in non-financial goals that require alternative success measures such as independence, job satisfaction, or opportunity to achieve life-work success (Buttner \& Moore, 1997; Green \& Cohen, 1995; Kuratko et al., 1997; Parasuraman et al., 1996), which are personal and perceived subjectively, and therefore more complex to ascertain. Because of this, Walker and Brown (2004) conclude that economic standards are usually regarded as the most suitable yardstick for research into business success/performance, because they are easier to understand and more convenient to compare, both in terms of the existing data and for future evaluation. Based on the above, the author's decision is to use indicators of survival in business (measured by the number of months of total business operations), profit, total revenue and growth indicators (measured by changes in revenue, changes in profit, changes in number of employees and changes in assets) as the objective measure of the performance of small enterprises. Annual income was not accepted as a sole indicator of success since there are companies whose expenditures are higher than incomes, 
which means that their operations could not, by any means, be described as successful (Mihic et al., 2015). Although Gray (1998) states that owners of small and medium-sized enterprises are reluctant to increase the number of employees because they consider new employees as an additional cost rather than an investment, and Walker and Brown (2004) suggest that the number of employees is not the accurate or applicable measure of success for small businesses, Reijonen and Komppula (2007) point out the number of employees as one of the most important indicators of growth and success of small enterprises, so this measure will be used as one of the indicators of the performance of small enterprises.

\section{Methodology}

\subsection{Sample and data}

The administrative classification of companies in Serbia under the Law on Accounting and Auditing ("Official Gazette of the Republic of Serbia", No. 62/2013 and 30/2018) recognizes the group - the sector of small and medium enterprises and entrepreneurship. The sample based on small enterprises, in addition to the criteria of the number of employees, income and assets, is further differentiated by separation from medium-sized enterprises and entrepreneurs. Stratification was performed on the basis of administrative regions. According to the available data of the Business Registers Agency, a total of 2603 enterprises are classified in the group of small enterprises. The survey was conducted on 150 observations. The sample has the characteristics of a proportional stratified sample. Stratification was based on the region so that the basic set from the spatial aspect is adequately represented. As shown in the previous part of the paper, the selected field of research is a subgroup of small enterprises, which excludes the category of micro enterprises (enterprises up to 10 employees). What makes small enterprises seem to be an officially accepted subject of economic activity is their management orientation and the declaration of intention for a long-term existence and achieving their mission. The existence of management orientation clearly separates a small enterprise from an entrepreneurial venture as visually explained by Wickham (2004). However, the initial management practice also qualitatively segregates small businesses from the mediumsized to a significant extent, as the next administrative stage in development, where management is present at a higher, mainly professional level. That is why small businesses separated from the medium-sized segment with the excluded category of micro enterprises represent one homogeneous group or a qualitatively precise and clearly defined area of research. In the next segment, it is necessary to identify research variables in order to create preconditions for formulating research assumptions and adequate interpretation of research results at a satisfactory level of reliability and usability.

\subsection{Variables, hypotheses and methods}

The set concept of work seeks to examine the correlation of business performance variables, measured by indicators of profit and revenue growth, with variables of volume and structure of financing as is equity and percentage of equity as a structure. Measures such as business time, total revenue and total number of employees, represent the size and age of business. Companies of varying volumes and duration on the market may have varying characteristics in terms of organization and environment, which of course may have an effect on their performance. The variables below were included as controls for this reason.

Based on the above stated we start from the following research assumptions:

$\mathrm{HO}$ : There is a statistically significant correlation between the volume and structure of sources of financing and the performance of small enterprises;

$\mathrm{H} 1$ : There is a statistically significant correlation between the volume of sources of financing and the performance of small enterprises;

$\mathrm{H} 2$ : There is a statistically significant correlation between the volume of own capital and the performance of small enterprises.

In accordance with this research question, quantitative methods will be used for the research of relationship/correlation between selected research variables based on regression analysis and parametric characteristics of Pearson correlation coefficient.

\section{Results and Discussion}

A variety of factors determine the nature and specificity of small businesses, which defines the overall operation of small businesses and makes them different. Any generalization during research and conclusions on operations of this type of enterprises is far more difficult and with a lower degree of reliability. 
Such circumstances are influenced by the distinct personalization of the business entity, the inaccessibility of business data, and the omission of non-measurable factors of high influence on the area of small enterprises.

Based on the research concept and the goal of the research, the nature of the relations between the selected variables and the results of the research in Table 1 were examined using the regression analysis at the level of the parametric alternative. In the analysis of the results of the research, we will primarily focus on the main goal of the research regarding the impact of the type of financing on the performance of small enterprises. In the financing area, indicators of total financing sources, growth of financing sources, own capital as well as increase of own capital were analysed.

Table 1. Correlations

\begin{tabular}{|c|c|c|c|c|c|c|c|c|c|c|c|c|}
\hline & & $\begin{array}{l}\text { Total } \\
\text { assets } \\
2017\end{array}$ & \begin{tabular}{|c|} 
Average \\
number of \\
employees \\
2017
\end{tabular} & $\begin{array}{c}\text { Total } \\
\text { revenue } \\
2017\end{array}$ & $\begin{array}{l}\text { Profit } \\
2017\end{array}$ & $\begin{array}{c}\text { Own } \\
\text { capital }\end{array}$ & $\begin{array}{l}\% \text { of } \\
\text { own } \\
\text { capital }\end{array}$ & $\begin{array}{c}\text { Number } \\
\text { of } \\
\text { months } \\
\text { of } \\
\text { business }\end{array}$ & $\begin{array}{c}\begin{array}{c}\% \text { of } \\
\text { increase } \\
\text { in the } \\
\text { number of } \\
\text { employees }\end{array} \\
\end{array}$ & $\begin{array}{c}\% \text { of } \\
\text { asset } \\
\text { growth }\end{array}$ & $\begin{array}{c}\% \text { of } \\
\text { growth } \\
\text { in total } \\
\text { revenue }\end{array}$ & $\begin{array}{c}\% \text { of } \\
\text { profit } \\
\text { growth }\end{array}$ \\
\hline Total assets 2018 & $\begin{array}{l}\text { Pearson } \\
\text { Correlation } \\
\text { Sig. (2-tailed) } \\
\text { N }\end{array}$ & $\begin{array}{r}1 \\
150\end{array}$ & & & & & & & & & & \\
\hline $\begin{array}{l}\text { Average number } \\
\text { of employees } \\
2018\end{array}$ & $\begin{array}{l}\text { Pearson } \\
\text { Correlation } \\
\text { Sig. (2-tailed) } \\
\mathrm{N}\end{array}$ & $\begin{array}{r}.124 \\
.132 \\
150\end{array}$ & 150 & & & & & & & & & \\
\hline $\begin{array}{l}\text { Total revenue } \\
2018\end{array}$ & $\begin{array}{l}\text { Pearson } \\
\text { Correlation } \\
\text { Sig. (2-tailed) } \\
\mathrm{N}\end{array}$ & $\begin{array}{r}.546^{* *} \\
.000 \\
150\end{array}$ & $\begin{array}{r}.170^{\star} \\
.037 \\
150\end{array}$ & 150 & & & & & & & & \\
\hline Profit 2018 & $\begin{array}{l}\text { Pearson } \\
\text { Correlation } \\
\text { Sig. (2-tailed) } \\
\mathrm{N}\end{array}$ & $\begin{array}{l}.543^{\star *} \\
.000 \\
150\end{array}$ & $\begin{array}{r}-.113 \\
.168 \\
150\end{array}$ & $\begin{array}{r}.710^{\star *} \\
.000 \\
150\end{array}$ & 150 & & & & & & & \\
\hline Own capital & $\begin{array}{l}\text { Pearson } \\
\text { Correlation } \\
\text { Sig. (2-tailed) } \\
\text { N }\end{array}$ & $\begin{array}{r}.934^{\star *} \\
.000 \\
150\end{array}$ & $\begin{array}{l}.073 \\
.376 \\
150\end{array}$ & $\begin{array}{c}.501^{\star *} \\
.000 \\
150\end{array}$ & $\begin{array}{c}.568^{* *} \\
.000 \\
150\end{array}$ & 150 & & & & & & \\
\hline$\%$ of own capital & $\begin{array}{l}\text { Pearson } \\
\text { Correlation } \\
\text { Sig. (2-tailed) } \\
\mathrm{N}\end{array}$ & $\begin{array}{r}.085 \\
.301 \\
150 \\
\end{array}$ & $\begin{array}{r}-.117 \\
.154 \\
150\end{array}$ & $\begin{array}{r}.057 \\
.487 \\
150 \\
\end{array}$ & $\begin{array}{r}.111 \\
.176 \\
150 \\
\end{array}$ & $\begin{array}{r}.243^{\star \star} \\
.003 \\
150\end{array}$ & 150 & & & & & \\
\hline $\begin{array}{l}\text { Number of } \\
\text { months of } \\
\text { business }\end{array}$ & $\begin{array}{l}\text { Pearson } \\
\text { Correlation } \\
\text { Sig. (2-tailed) } \\
\mathrm{N}\end{array}$ & $\begin{array}{r}.011 \\
.898 \\
150\end{array}$ & $\begin{array}{r}-.063 \\
.445 \\
150\end{array}$ & $\begin{array}{r}-.016 \\
.841 \\
150\end{array}$ & $\begin{array}{r}-.002 \\
.980 \\
150\end{array}$ & $\begin{array}{r}.058 \\
.483 \\
150\end{array}$ & $\begin{array}{r}.132 \\
.108 \\
150\end{array}$ & 150 & & & & \\
\hline $\begin{array}{l}\% \text { of increase in } \\
\text { the number of } \\
\text { employees }\end{array}$ & \begin{tabular}{|l|} 
Pearson \\
Correlation \\
Sig. (2-tailed) \\
$\mathrm{N}$ \\
\end{tabular} & $\begin{array}{r}-.047 \\
.566 \\
150 \\
\end{array}$ & $\begin{array}{c}.180^{\star} \\
.027 \\
150\end{array}$ & $\begin{array}{r}.025 \\
.759 \\
150 \\
\end{array}$ & $\begin{array}{r}-.023 \\
.775 \\
150 \\
\end{array}$ & $\begin{array}{r}-.071 \\
.388 \\
150\end{array}$ & $\begin{array}{r}-.110 \\
.182 \\
150\end{array}$ & $\begin{array}{r}-.220^{\star *} \\
.007 \\
150\end{array}$ & 150 & & & \\
\hline$\%$ of asset growth & $\begin{array}{l}\text { Pearson } \\
\text { Correlation } \\
\text { Sig. (2-tailed) } \\
\mathrm{N}\end{array}$ & $\begin{array}{r}.205^{*} \\
.012 \\
150\end{array}$ & $\begin{array}{r}.124 \\
.131 \\
150\end{array}$ & $\begin{array}{r}.241^{\star \star} \\
.003 \\
150\end{array}$ & $\begin{array}{r}.144 \\
.079 \\
150\end{array}$ & $\begin{array}{r}.105 \\
.202 \\
150\end{array}$ & $\begin{array}{r}-.157 \\
.055 \\
150\end{array}$ & $\begin{array}{r}.002 \\
.985 \\
150\end{array}$ & $\begin{array}{r}.134 \\
.102 \\
150\end{array}$ & 150 & & \\
\hline $\begin{array}{l}\% \text { of growth in } \\
\text { total revenue }\end{array}$ & $\begin{array}{l}\text { Pearson } \\
\text { Correlation } \\
\text { Sig. (2-tailed) } \\
\text { N }\end{array}$ & $\begin{array}{r}-.037 \\
.654 \\
150\end{array}$ & $\begin{array}{r}.085 \\
.300 \\
150\end{array}$ & $\begin{array}{r}.155 \\
.058 \\
150\end{array}$ & $\begin{array}{r}.164^{*} \\
.045 \\
150\end{array}$ & $\begin{array}{r}.052 \\
.525 \\
150\end{array}$ & $\begin{array}{r}.014 \\
.862 \\
150\end{array}$ & $\begin{array}{r}-.098 \\
.232 \\
150\end{array}$ & $\begin{array}{r}.385^{\star *} \\
.000 \\
150\end{array}$ & $\begin{array}{r}.131 \\
.109 \\
150\end{array}$ & 150 & \\
\hline$\%$ of profit growth & $\begin{array}{l}\text { Pearson } \\
\text { Correlation } \\
\text { Sig. (2-tailed) } \\
\mathrm{N}\end{array}$ & $\begin{array}{r}.005 \\
.950 \\
150 \\
\end{array}$ & $\begin{array}{l}.008 \\
.924 \\
150 \\
\end{array}$ & $\begin{array}{c}.059 \\
.476 \\
150 \\
\end{array}$ & $\begin{array}{l}.055 \\
.504 \\
150 \\
\end{array}$ & $\begin{array}{r}-.009 \\
.915 \\
150 \\
\end{array}$ & $\begin{array}{r}-.026 \\
.748 \\
150 \\
\end{array}$ & $\begin{array}{r}.055 \\
.504 \\
150 \\
\end{array}$ & $\begin{array}{r}.114 \\
.165 \\
150 \\
\end{array}$ & $\begin{array}{r}.037 \\
.652 \\
150 \\
\end{array}$ & $\begin{array}{r}.234^{\star \star} \\
.004 \\
150 \\
\end{array}$ & 150 \\
\hline
\end{tabular}

**. Correlation is significant at the 0.01 level (2-tailed).

*. Correlation is significant at the 0.05 level (2-tailed). 
Based on the results shown in the table, when it comes to the relationship between total financing sources and own capital, there is a strong positive correlation at the level of statistical significance, with values $r=$ .934 (Cohen, 1988), $n=150, p=.000$ with coefficient of determination of $87.23 \%$, which shows a common part of variance of two variables. We can say, based on these results, that the participation of own capital follows the movement of total financing sources, which indicates a stable structure. After consideration of financing structure results, the following comparison is carried out between the volume of the financing sources and the selected performance indicators. The result worth considering is the ratio of total financing sources and total revenue, as an indicator of performance; there is a strong positive correlation at the level of statistical significance, with values $r=.546, n=150, p=.000$ with a coefficient of determination of $29.81 \%$ which indicates a common part of the variance of the two variables.

Table 2. Model summary

\begin{tabular}{l|c|c|c|c|}
\hline Model & $\mathbf{R}$ & $\begin{array}{c}\text { R } \\
\text { Square }\end{array}$ & $\begin{array}{c}\text { Adjusted R } \\
\text { Square }\end{array}$ & $\begin{array}{c}\text { Std. Error of } \\
\text { the Estimate }\end{array}$ \\
\hline 1 & $.791^{\text {a }}$ & .626 & .610 & 20954.358 \\
\hline
\end{tabular}
a. Predictors: (Constant), \% Equity, Total Revenue 2018, Business Period
(31.12.2018.), Average Number of Employees 2018, Equity, Total
Assets/Liabilities 2018
b. Dependent Variable: Profit in 2018

The following result, that sets out the volume of financing sources and performance, relates to profits; there is a strong positive correlation at the level of statistical significance, with values $r=.543, n=150, p=.000$ with a coefficient of determination of $29.48 \%$ which indicates a common part of the variance of two variables. A significant result, in the selected performance variables and in relation to the volume of financing, appears also in the percentage of asset growth. Between these two variables there is a slight positive correlation, however, at the level of statistical significance with values $r=.205, n=150, p=.012$ with a coefficient of determination of $4.20 \%$, which indicates a common part of the variance of two variables, which is in this case negligible. In the analysis of results in the area of the own capital influence (absolute value) on the performance indicators, the profit in the form of a strong positive correlation at the level of statistical significance stands out, with values $r=.568, n=150, p=.000$ with a coefficient of determination of $32.26 \%$ indicating a common part of the variance of two variables. In the analysis of the interdependence between the variable of own capital and the performance, a statistically significant, strong positive correlation with the variable of total revenue and values $r=.501, n=150, p=.000$ with a coefficient of determination of $25.10 \%$ stands out, which indicates a common part of the variance of two variables. Other selected business performance variables did not manifest significant correlation with respect to variables of volume and structure of financing sources.

Table 3. ANOVAa

\begin{tabular}{|l|l|l|r|r|r|r|}
\hline \multicolumn{2}{|c|}{ Model } & Sum of Squares & df & Mean Square & F & Sig. \\
\hline \multirow{3}{*}{1} & Regression & 104975852565.069 & 6 & 17495975427.512 & 39.846 & $.000^{\mathrm{b}}$ \\
\cline { 2 - 8 } & Residual & 62789170184.804 & 143 & 439085106.187 & & \\
\cline { 2 - 8 } & Total & 167765022749.873 & 149 & & & \\
\hline
\end{tabular}

a. Dependent Variable: Profit in 2018

b. Predictors: (Constant), \% Equity, Total Revenue 2018, Business Period (31.12.2018.), Average Number of Employees 2018, Equity, Total Assets/Liabilities 2018

Source: Authors' Calculation

Following the Pearson correlation, a standard multiple regression procedure was performed in an effort to determine the impact of a group of independent variables of dominant volume and funding structure on performance (profit) indicators. The model was evaluated as a whole, significance was determined and individual evaluation of each independent variable in the model was performed. 
Table 4. Coefficients ${ }^{a}$

\begin{tabular}{|c|c|c|c|c|c|c|c|c|c|c|c|c|c|}
\hline \multirow{2}{*}{\multicolumn{2}{|c|}{ Model }} & \multicolumn{2}{|c|}{$\begin{array}{c}\text { Unstandardized } \\
\text { Coefficients }\end{array}$} & \multirow{2}{*}{$\begin{array}{c}\begin{array}{c}\text { Standardized } \\
\text { Coefficients }\end{array} \\
\text { Beta }\end{array}$} & \multirow{2}{*}{$t$} & \multirow{2}{*}{ Sig. } & \multicolumn{2}{|c|}{$\begin{array}{c}95 \% \text { Confidence } \\
\text { Interval for B }\end{array}$} & \multicolumn{3}{|c|}{ Correlations } & \multicolumn{2}{|c|}{$\begin{array}{c}\text { Colinearity } \\
\text { Statistics }\end{array}$} \\
\hline & & B & Std. Error & & & & $\begin{array}{l}\text { Lower } \\
\text { Bound }\end{array}$ & $\begin{array}{l}\text { Upper } \\
\text { Bound }\end{array}$ & $\begin{array}{l}\text { Zero- } \\
\text { order }\end{array}$ & Partial & Part & Tolerance & VIF \\
\hline \multirow{7}{*}{1} & (Constant) & 7215.2 & 10331.476 & & .698 & .486 & -13206.85 & 27637.445 & & & & & \\
\hline & $\begin{array}{l}\text { Business Period } \\
(31.12 .2018 .)\end{array}$ & -9.810 & 19.207 & -.026 & -.511 & .610 & -47.776 & 28.157 & -.002 & -.043 & -.026 & .974 & 1.02 \\
\hline & $\begin{array}{l}\text { Average Number } \\
\text { of Employees } \\
2018\end{array}$ & -365.7 & 81.744 & -.235 & -4.475 & .000 & -527.351 & $-204,184$ & -.113 & -.350 & -.229 & .947 & 1.05 \\
\hline & $\begin{array}{l}\text { Total } \\
\text { Assets/Liabilities } \\
2018\end{array}$ & -.029 & .019 & -.246 & $-1,514$ & .132 & -.066 & .009 & .543 & -.126 & -.077 & .099 & 10.0 \\
\hline & $\begin{array}{l}\text { Total Revenue } \\
2018\end{array}$ & .095 & .009 & .630 & 10.224 & .000 & .077 & .114 & .710 & .650 & .523 & .690 & 1.45 \\
\hline & Equity & .071 & .022 & .513 & 3.167 & .002 & .027 & .115 & .568 & .256 & .162 & .100 & 10.0 \\
\hline & $\%$ Equity & -90.6 & 100.085 & -.053 & -.906 & .366 & -288.522 & 107.153 & .111 & -.076 & -.046 & .773 & 1.29 \\
\hline
\end{tabular}

a. Dependent Variable: Profit in 2018

Source: Authors' Calculation

Prior to analysing the results of the set model of multiple regression, we want to point out the fulfilment of the assumption of multicollinearity. In addition to the correlation coefficients, the values of Tolerance and VIF indicate this assumption. Having in mind the limit values of the mentioned indicators (Tolerance $<0.10$; VIF $>10$ ) in Table 4, we can say that the values are the indicator of all variables in the domain of limit values and that there is no problem of multicollinearity of variables included in the model. Table 2, model summary, presents the result that evaluates the whole model using the coefficient of determination, $r^{2}$. The coefficient of determination gives the answer to the question: which part of the variance of the dependent variable explains the model, i.e., the group of selected independent variables. The value of the coefficient of determination is $r^{2}=.626$, expressed as a percentage, the model explains $62.60 \%$ of the variance of the dependent variable or profit. In this case, the value of the corrected coefficient of determination does not need to be included in the analysis, since the sample size is significant, the actual value of the coefficient of determination is stable and there are no significant deviations from the corrected value of the coefficient. The prediction of the model, i.e., the value of the coefficient of determination is statistically significant, which can be seen based on the results of ANOVA in Table 3, which are $F(6,143)=39.846, p<0,000$. When evaluating each independent variable in the model, in order to determine their individual contribution to the total predictive power of the model, we will compare the standardized values of the Beta coefficient. The highest absolute value of the Beta coefficient has the variable Total Revenue $2018(0.63), p=0.000$, which means that Total Revenue gives a statistically significant largest unique contribution to the model. The variable with a slightly smaller contribution at the level of statistical significance is the variable Equity, the value of the Beta coefficient is 0.513 and $p=0.002$. In addition to the above two, another variable with a significantly smaller contribution but statistically significant is the Average Number of Employees 2018, where the value of the Beta coefficient is 0.513 and $p=0.002$. These characteristics make a unique and statistically significant contribution to profit prediction as an indicator of performance/success. Other significant results in the coefficient table (Table 4) are the semi-partial correlation coefficients in the Part column. When this indicator is squared, the indicator of the contribution of a certain variable to the total coefficient of determination is obtained. Thus, the value of the variable Total Revenue has a semi-partial correlation coefficient of 0.523 when squared, a value of 0.27 is obtained, which shows that Total Revenue independently explains $27 \%$ in the values of the variable Profit. The value of the variable Equity has a semi-partial correlation coefficient of 0.162 ; when squared, a value of 0.026 is obtained, which shows that Equity independently explains $2.6 \%$ in the values of the variable Profit. The variable Average Number of Employees has a semipartial correlation coefficient -0.229 ; when squared the value is 0.053 , which shows that the Average Number of Employees independently explains $5.3 \%$ in the values of the variable Profit. Compared to similar studies in Serbia, we can say that the results are identical. The financial problems of small enterprises in Serbia are a consequence of the unfavourable influence of financial leverage, growth of financial risk and inadequate financial structure. All these problems have reduced efficiency growth, which has negatively affected this segment of the economy (Stevanovic et al., 2017). The study conducted in the USA produced results based on which it can be concluded that cost-effective companies rely more on loans as their predominant source of financing. Despite the fact that interest on operating loans is tax deductible, increase in default risk results from higher debt levels, which, in turn, exposes companies to increased chance of bankruptcy (Gill et al., 2011). 


\section{Conslusion}

The facts in the conclusion are provided, not by chance, but because of their significance when it comes to the deficiency of financial indicators in the analysis of small business operations. Taking into account all the prominent specifics of small enterprises, in the subjective-objective relation, we point out the following deficiencies of financial indicators in small enterprises: indicators provide insignificant presentation if the company incurs loss; there is no clear definition specifically when it comes to the indicator; if we take into account the previous fact, the indicators can be calculated in the way that someone wants or in a way that suits them, which means that indicators can be subject to manipulation; following previous two points, the indicators are most often presented in the final statement without certain accompanying calculations or definitions; in the domain of analysis there are only financial indicators, while all other factors that may have consequences for the company's results are missing; if calculated over a long period of time for the purposes of long-term analysis, the monetary value is not the same throughout the year of the selected period due to the effects of inflation (Hughes et al., 2007).

Considering all of the above, we approach the process of making conclusions in regard to research structure with a certain amount of reserve. The main results of the paper show that the volume of financing as well as the participation of own capital do contribute to the business result/performance of small enterprises which are measured by the most relevant variables in terms of profit and total revenue.

Based on the presented results of the survey within the analyzed sample, when considering the structure of capital, we can reach the conclusion that small enterprises rely heavily on their own capital (over $80 \%$ ), which affects the stability of the business and also the business result and competitiveness. Identical confirmation is found in similar research conducted in Serbia by Stevanovic, Ivanovic-Djukic and Lepojevic (2017). Based on the above research, we can see that the number of entrepreneurs has increased (at a rate of 58\% in the period from 2004 to 2009). On the other hand, there are negative tendencies in the form of an increase in long-term liabilities (at a rate of $815 \%$ from 2004-2009). These trends resulted in a significant change in terms of indebtedness and increased financial risk, which ultimately affected the financial structure. There was a short-term effect in terms of business results, as financial problems arose very quickly. (Stevanovic et al., 2017). Similar results are found at the global level, especially in research conducted in the USA. Having reviewed the findings of research presented in this article, it can be deduced that the structure of a company's capital influences profitability and is an optimum debt/equity ratio for the company, which will consequently reduce the cost of capital, i.e., the financing cost of the firm's operations to the most favourable level (Gill, Biger, \& Mathur, 2011).

When it comes to comparing the variables of the volume of financing sources and performance, significance is present in total revenue, profits and growth indicators in the domain of assets. The relation of the own capital variable is expressed in relation to the variable of the performance in terms of profit.

The key contribution of this research is identification of optimal financing structure for business performance/success of small enterprises.

Based on the facts presented, we can say that all research assumptions have been confirmed, and the presented research results are significant and representative. We need to point out that the acceptance of set hypotheses is based on one part of the selected performance variables for which, compared to the claims in the theoretical part, we can say that are the most representative within the defined research field.

Future research in so defined an area and research problem may go in the direction of expanding the list of variables from the segment of the scope and structure of funding, while the success/performance segment could be expanded by subjective measures.

\section{REFERENCES}

[1] Bardi, A., \& Schwartz, S. H. (2003). Values and behavior: Strength and structure of relations. Personality and social psychology bulletin, 29(10), 1207-1220. DOI:10.1177/0146167203254602

[2] Beck, T., Demirgüç-Kunt, A., \& Maksimovic, V. (2008). Financing patterns around the world: Are small firms different? Journal of Financial Economics, 89(3), 467-487. DOI:10.1016/j.jfineco.2007.10.005

[3] Berger, A., \& G. Udell (1995). Relationship Lending and Lines of Credit in Small Firm Finance, Journal of Business, 68(3), 351-381. DOI:10.1086/296668

[4] Brinckmann, J., Grichnik, D., \& Kapsa, D. (2010). Should entrepreneurs plan or just storm the castle? A meta-analysis on contextual factors impacting the business planning-performance relationship in small firms. Journal of Business Venturing, 25(1), 24 - 40. DOI:10.1016/j.jbusvent.2008.10.007

[5] Bruderl, J., Preisendorfer, P., \& Ziegler, R. (1992). Survival chances of newly founded business organizations. American sociological review, 57(2), 227-242. DOI:10.2307/2096207 
[6] Brush, C. G., \& Vanderwerf, P. A. (1992). A comparison of methods and sources for obtaining estimates of new venture performance. Journal of Business Venturing, 7(2), 157-170. DOI:10.1016/08839026(92)90010-O

[7] Burns, P., \& Dewhurst, J. (Eds.). (2016). Small business and entrepreneurship. Macmillan International Higher Education. DOI:10.1007/978-1-137-43034-2

[8] Buttner, E. H., \& Moore, D. P. (1997). Women's organizational exodus to entrepreneurship: self-reported motivations and correlates with success. Journal of small business management, 35, 34-46.

[9] Cohen, J. (1988). Statistical Power Analysis for the Behavioral Sciences (2nd ed.). Hillsdale, NJ: Lawrence Erlbaum Associates, Publishers.

[10] Cressy, R., \& Olofsson, C. (1997). The financial conditions for Swedish SMEs: Survey and research agenda. Small business economics, 9(2), 179-192. DOI:10.1023/A:1007975924164

[11] Cuervo, Á., Ribeiro, D., \& Roig, S. (2007). Entrepreneurship: concepts, theory and perspective. Springer, Berlin, Heidelberg. DOI:10.1007/978-3-540-48543-8

[12] D'Amato, A. (2019). Capital structure, debt maturity, and financial crisis: empirical evidence from SMEs. Small Business Economics, 1-23.

[13] Dobbins, R., \& Pettman, B. O. (1997). Self-development: the nine basic skills for business success. Journal of management development, 16(8), 521-667. DOI:10.1108/02621719710174011

[14] Gill, A., Biger, N., \& Mathur, N. (2011). The effect of capital structure on profitability: Evidence from the United States. International Journal of Management, 28(4), 3.

[15] Gray, C. (1998). Managing Entrepreneurial growth: a question of control?", in Deakins, D., Jennings, P. and Mason, C. (Eds), Small Firms: Entrepreneurship in the Nineties, Paul Chapman Publishing, London.

[16] Green, E., \& Cohen, L. (1995). 'Women's business': Are women entrepreneurs breaking new ground or simply balancing the demands of 'women's work' in a new way?. Journal of Gender studies, 4(3), 297314. DOI:10.1080/09589236.1995.9960615

[17] Hall, G., \& Fulshaw, S. (1991). Factors associated with relative performance amongst small firms in the British instrumentation sector. Manchester, UK: Manchester Business School.

[18] Hamilton, R. T., \& Fox, M. A. (1998). The financing preferences of small firm owners. International Journal of Entrepreneurial Behavior \& Research, 4(3), 239-248. DOI:10.1108/13552559810235529

[19] Hill, J. (2001). A multidimensional study of the key determinants of effective SME marketing activity: Part 1. International Journal of Entrepreneurial Behavior \& Research, 7(5), 171-204. DOI:10.1108/EUM0000000006006

[20] Hogerle, B., Charifzadeh, M., Ferencz, M., \& Kostin, K. B. (2020). The development of working capital management and its impact on profitability and shareholder value: evidence from Germany. Strategic Management, 25(2), 27-39.

[21] Hughes, F.J., Simpson, M., \& J. Padmore (2007). Inherent Limitations in Using Financial Ratio Analysis to Assess Small and Medium Sized Company Performance. The Management School, University of Sheffield.

[22] Ivanis, M. (2012). Elements of corporate capital structure. Law and Economics Views, 3(2), 28-56. (Elementi strukture kapitala korporativnog preduzeca. Pravno-Ekonomski pogledi, 3(2), 28-56).

[23] Jakovcevic, K., Komazec, Lj., \& Tomic, S. (2012). Economics of the company. University of Novi Sad, Faculty of Economics Subotica, Serbia. (Ekonomika preduzeca. Univerzitet u Novom Sadu, Ekonomski fakultet u Subotici, Srbija).

[24] Jennings, P., \& Beaver, G. (1997). The performance and competitive advantage of small firms: a management perspective. International small business journal, 15(2), 63-75. DOI:10.1177/0266242697152004

[25] Jevtic, M., Jovanovic, M., \& Krivokapic, J. (2018). A new approach to measuring the correlation of organizational alignment and performance. Management: Journal of Sustainable Business and Management Solutions in Emerging Economies, 23(1), 41-52. DOI:10.7595/management.fon.2017.0029

[26] Klapper, L. F., Sarria-Allende, V., \& Sulla, V. (2002). Small-and medium-size enterprise financing in Eastern Europe. The World Bank. DOI:10.1596/1813-9450-2933

[27] Kuratko, D. F., Hornsby, J. S., \& Naffziger, D. W. (1997). An examination of owner's goals in sustaining entrepreneurship. Journal of small business management, 35(1), 24-33.

[28] Laitinen, E. K. (2002). A dynamic performance measurement system: evidence from small Finnish technology companies. Scandinavian journal of management, 18(1), 65-99. DOI:10.1016/S0956$5221(00) 00021-X$

[29] Law on Accounting and Auditing of the Republic of Serbia ("Official Gazette of the Republic of Serbia", No. 62/2013 and 30/2018.

[30] Lekovic, B., \& Maric, S. (2015). Models of external management support in small enterprises. Synthesis International Scientific Conference of IT and Business-Related Research, 388-393.

[31] Lekovic, B., \& Maric, S. (2016). Innovativeness as a source of competitive advantage for entrepreneurial ventures and small business. Strategic Management, 21(3), 3-12. 
[32] Malhotra, M., Chen, Y., Criscuolo, A., Fan, Q., Hamel, I. I., \& Savchenko, Y. (2007). Expanding access to finance: Good practices and policies for micro, small, and medium enterprises. The World Bank. DOI:10.1596/978-0-8213-7177-0

[33] Mateev, M., Poutziouris, P., \& Ivanov, K. (2013). On the determinants of SME capital structure in Central and Eastern Europe: A dynamic panel analysis. Research in International Business and Finance, 27(1), 28-51. DOI:10.1016/j.ribaf.2012.05.002

[34] Mc Cartan-Quinn, D., \& Carson, D. (2003). Issues which impact upon marketing in the small firm. Small business economics, 21(2), 201-213. DOI:10.1023/A:1025070107609

[35] Mihic, M. M., Arsic, S. M., \& Arsic, M. Z. (2015). Impacts of entrepreneurs' stress and family members on SMEs' business success in Serbian family-owned firms. Journal of East European Management Studies, $452-483$.

[36] Motta, V. (2020). Lack of access to external finance and SME labor productivity: does project quality matter?. Small Business Economics, 54(1), 119-134.

[37] Murphy, G. B., Trailer, J. W., \& Hill, R. C. (1996). Measuring performance in entrepreneurship research. Journal of business research, 36(1), 15-23. DOI:10.1016/0148-2963(95)00159-X

[38] Parasuraman, S., Purohit, Y. S., Godshalk, V. M., \& Beutell, N. J. (1996). Work and family variables, entrepreneurial career success, and psychological well-being. Journal of vocational behavior, 48(3), 275-300. DOI:10.1006/jvbe.1996.0025

[39] Pennings, J. M., Lee, K., \& Witteloostuijn, A. V. (1998). Human capital, social capital, and firm dissolution. Academy of management Journal, 41(4), 425-440. DOI:10.2307/257082

[40] Perez, E. H., \& Canino, R. M. B. (2009). The importance of the entrepreneur's perception of "success". Review of International Comparative Management, 10(5), 990-1010.

[41] Reijonen, H., \& Komppula, R. (2007). Perception of success and its effect on small firm performance. Journal of Small Business and Enterprise Development, 14(4), 689-701. DOI: $10.1108 / 14626000710832776$

[42] Scarborough, N. (2012). Effective Small Business Management, An Entrepreneurial Approach, tenth edition, Pearson Education Limited.

[43] Scherr, F. C., Sugrue, T. F., \& Ward, J. B. (1993). Financing the small firm start-up: Determinants of debt use. The Journal of Entrepreneurial Finance, 3(1), 17-36.

[44] Schwab, K. World Economic Forum (2017). The Global Competitiveness Report 2017-2018,

[45] Schwartz, S. H. (2012). An overview of the Schwartz theory of basic values. Online readings in Psychology and Culture, 2(1), 11. DOI:10.9707/2307-0919.1116

[46] Simpson, M., Tuck, N., \& Bellamy, S. (2004). Small business success factors: the role of education and training. Education+ Training, 46(8/9), 481-491. DOI:10.1108/00400910410569605

[47] Stevanovic, T., Ivanovic-Djukic, M., \& Lepojevic, V. (2017). Impact of the Financial Structure on the Efficiency of Entrepreneurs in Serbia. Montenegrin Journal of Economics, 13(3), 19-30.

[48] Stokes, D., Wilson, N., \& Wilson, N. (2010). Small business management and entrepreneurship. Cengage Learning EMEA, Hampshire.

[49] Thanh, L.T., \& Hu ong, D.M. (2017). Determinants of capital structure: an empirical study on Vietnamese listed firms. Serbian Journal of Management 12 (1), 77-92. DOI:10.5937/sjm12-10187

[50] Virtanen, M. (1999). Strategies of growth and finance in an enterprise. Strategic Entrepreneurship, 120143.

[51] Vrchota, J., \& Rehor, P. (2017). Influence of strategies to determine the significance of the crisis by the managers of small and medium-sized enterprises. Serbian Journal of Management, 12(1), 53-63.

[52] Vuckovic, B., Veselinovic, B., \& Vuckovic, A. (2017). Adequate asset structure as a foundation for profitability of agricultural enterprises. The Annals of the Faculty of Economics in Subotica, (38), 51-68.

[53] Walker, E., \& Brown, A. (2004). What Success Factors are Important to Small Business Owners? International Small Business Journal, 22(6), 577-594. DOI:10.1177/0266242604047411

[54] Walker, M. M. (1998). Leveraged recapitalizations, operating efficiency, and stockholder wealth. Financial Review, 33(3), 99-114. DOI:10.1111/j.1540-6288.1998.tb01385.x

[55] Wickham, P. (2004). Strategic entrepreneurship, Prentice Hall. 


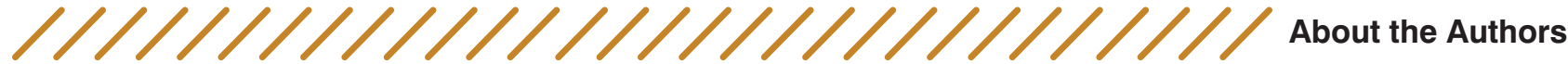

\author{
Aleksandra Stoiljković \\ University of Novi Sad, Faculty of Economics, Subotica, Serbia \\ astoiljkovic@ef.uns.ac.rs
}

Aleksandra Stoiljković is a Teaching Assistant at the Department of Management, Faculty of Economics in Subotica, University of Novi Sad, Republic of Serbia. She teaches Business Economics and Economics in Tourism, at Undergraduate Studies and Cost Management and Modeling the Development of Tourism and Hospitality, at Master's Studies. She is a PhD student at the Faculty of Economics and the author of numerous papers in the field of Business Management and Economics in Tourism.

Slobodan Marić

University of Novi Sad, Faculty of Economics,Subotica, Serbia marics@ef.uns.ac.rs

Slobodan Marić is an Assistant professor at the Department of Management, Faculty of Economics Subotica, University of Novi Sad, Republic of Serbia, where he teaches bachelor's courses in Principles of Management and master's courses Performance Management and Contemporary Management. He has taken part in many national and international scientific and research projects. In addition, he is the author and coauthor of numerous scientific and professional papers in the fields of management, performance management, entrepreneurship and project management.
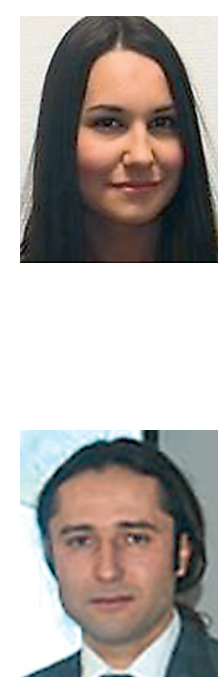